Huliaieva, H., Pasichnyk, L., Kharchuk, M., Kalinichenko, A., Patyka, V., Bohdan, M., Maksin, V. (2020): Influence of citrates nanoparticles on morphological traits of bacterial cells Pseudomonas syringae pv. atrofaciens. Agriculture and Forestry, 66 (1): 23-31.

DOI: 10.17707/AgricultForest.66.1.03

\author{
Hanna HULIAIEVA, Lidiia PASICHNYK, Maxim KHARCHUK, \\ Antonina KALINICHENKO*, Volodymyr PATYKA, \\ Mykhailo BOHDAN, Viktor MAKSIN ${ }^{1}$
}

\title{
INFLUENCE OF CITRATES NANOPARTICLES ON MORPHOLOGICAL TRAITS OF BACTERIAL CELLS PSEUDOMONAS SYRINGAE PV. ATROFACIENS
}

\section{SUMMARY}

Electron microscope investigations have revealed disintegration of the cell wall of Pseudomonas syringae pv. atrofaciens and subsequent killing of bacterial cells after application of $1 \%$ solutions of the citrates of $\mathrm{Ag}-\mathrm{Cu}$ nanoparticles, the complex Co-Cu-Zn-Fe-Mn-Mo-Mg (Avatar-1) and iodine-selenium. In field conditions, it was revealed that pre-sowing treatment of wheat seeds with the aforementioned $1 \%$ solutions significantly inhibited the development of basal glume rot in cereals with artificial infection of Pseudomonas syringae pv. atrofaciens. Consequently, reduction of the typical symptoms of basal glume rot of cereals and the percentage of isolated cells of Pseudomonas syringae pv. atrofaciens D13 were detected in wheat plants upon pre-sowing treatment of wheat seeds by experimental biocides. These results can be explained by structural changes in the bacterial cells of the pathogen that lead to reduction of viable forms of bacteria due to damage of both the cell wall and internal contents.

Keywords: Wheat, bacterial diseases, Pseudomonas syringae, nanoparticles.

\section{INTRODUCTION}

The soft wheat, due to its unique composition and high nutritional quality, is a widespread food crop in many countries of the globe. Wheat grains contain vitamins, minerals, protein, starch, fiber, etc. Thus, the protein content of wheat grain can range from $10 \%$ to $18 \%$ of the total dry matter. The selection aimed at improving the qualitative composition of the protein allowed the creation of new

\footnotetext{
${ }^{1}$ Antonina Kalinichenko (corresponding author: akalinichenko@uni.opole.pl), Institute of Technical Science; University of Opole, Dmowskiego str. 7-9, Opole, 45-365, POLAND; Information System and Technology Chair, Poltava State Agrarian Academy, Skovorody str, 1/3, Poltava, 36003, UKRAINE; Hanna Huliaieva, Lidiia Pasichnyk, Maxim Kharchuk, Volodymyr Patyka, Mykhailo Bohdan, Department of Phytopathogenic Bacteria, Zabolotny Institute of Microbiology and Virology of National Academy of Sciences of Ukraine, Acad. Zabolotny str. 154, Kyiv, 03680, UKRAINE; Viktor Maksin, National University of Biological Resources and Natural Resources of Ukraine, Heroiv Oborony Str.15, Kyiv. 03041, UKRAINE

Paper presented at the $10^{\text {th }}$ International Scientific Agricultural Symposium "AGROSYM 2019". Notes: The authors declare that they have no conflicts of interest. Authorship Form signed online. 
varieties with high protein content in the grain and improved amino acid composition. However, unfortunately, new varieties had undesirable characteristics, such as reduced yields and susceptibility to diseases and pests (Šramkováa, 2009; Kalinichenko et al., 2017).

One of the phytopathogenic microorganisms that cause significant loss of yield and quality is Pseudomonas syringae pv. atrofaciens - causal agent of basal glume rot of cereals. This disease under favorable meteorological conditions for its development can reach a considerable spreading and infect up to $80 \%$ of plants. The consequence of bacterial disease is the deterioration of the physical, technological and biochemical properties of the grain, reducing the content of glutenin and gliadin increasing the content of gluten of poor quality. In this case the following symptoms are observed: lesions of the lower part of the cover scales (maybe and upper), spots of various organs of plants. Brown, beige or black elongated blotches and streaks on different organs of diseased plants are observed throughout grain-filling period. With a significant defeat, the ear deforms and develops a succulent grain with a darker embryo (Gvozdyak et al., 2011).

So-called biocides, different in chemical composition, have a wide range of bactericidal properties. Among them compounds of silver, copper and halogens, in particular iodine. It is known that silver compounds interact with thiol groups of membrane bound enzymes, which plays an essential role in the inactivation of bacteria, causes the release of $\mathrm{K}^{+}$- ions from microorganism cells, inhibits the cell division, damages the cell membrane, precipitates in vacuoles and the cell wall in the form of granules, interacts with components of DNA, but the exact mechanism of action of these compounds is unknown. Halogens are oxidizers thiol groups to disulfides, sulfoxides or disulfoxides; they inhibit the synthesis of DNA. The compounds that contain chlorine or iodine more often are applied on practice as antiseptics and disinfectants. The antimicrobial action of iodine is fast, even at low concentrations. Its target is the key groups of proteins and amino acids, nucleotides and fatty acids, which leads to cell death (McDonnell and Russell, 1999).

At the same time, progress in science and the development of nanotechnologies has enabled the increase of the efficiency of these and other biogenic elements in times. Application of the nanoscale materials leads to a damage of the cell surface, changing in permeability of the membrane and death of the bacterial cell (Ahmada, 2017). Due to chelation by aqueous solution the citrate and small sizes (less than $100 \mathrm{~nm}$ ), the chelates of the nanoparticles of biogenic elements ease penetrate through the cell membrane and begin to rapidly act at the molecular level.

Therefore, the aim of our work was to study the bactericidal properties of various biocides: the chelated nanoscale metals in citrated form and biologically active iodine that effect on the morphological characteristics of bacterial cell, in particular, $P$. syringae pv. atrofaciens D13, which was isolated from wheat and rated as aggressive (aggressiveness 4 points). 


\section{MATERIAL AND METHODS}

For research citrates of nanoscale metals were used: $1 \%$ solution of Ag + $\mathrm{Cu}$ nano aqua citrate - from the preparation "Shumerske sriblo" with concentration of nanoparticles $\mathrm{Ag} 250 \mathrm{ml} / \mathrm{L}$ and with the concentration of nanoparticles $\mathrm{Cu} 250 \mathrm{mg} / \mathrm{L}$ and citric acid (Nanomaterials and nanotechnology Ltd, Ukraine); $1 \%$ solution composition of nanoparticles $\mathrm{Co}+\mathrm{Cu}+\mathrm{Zn}+\mathrm{Fe}+\mathrm{Mn}+\mathrm{Mo}+\mathrm{Mg}$, that is prepared from micro fertilizer Avatar-1 (organic), with composition of nanocomponents: Co - 0,0001-0,0025\%; $\mathrm{Cu}-$ 0,01-0,08\%; Zn - 0,001-0,007\%; Fe - 0,0015-0,008\%; Mn - 0,0005-0,005\%; Mo - 0,00001-0,0025\%; Mg - 0,01-0,08\% and citric acids - 0,5-10 mg/L, purified water ( Avatar Ltd, Ukraine) and a preparation of biologically active iodine in a complex with $1 \%$ solution selenium BP I-Se (preparation "Jodisconcentrate plus Se"). BP I-Se consists of purified water enriched with polyatomic ions I, $80 \mathrm{mg} / \mathrm{dm}^{3}$, Se citrate, intended as a biologically active food additive (SPC «Iodis», Ukraine).

Bacterial culture $P$. syringae pv. atrofaciens D13 was isolated from claybrown spot-strokes on a leaf-sheath of wheat, that was collected in the Dnipropetrovsk region. Isolation of bacteria from plant samples, inoculation and cultivation of them on solid medium and preparation of a bacterial suspension were performed according to generally accepted techniques (Patyka et al., 2016, 2017).

The morphological signs of bacterial cells for short-term effects of the test compounds, which were 15 minutes, were investigated using a transmission electron microscope JEOL JSM 1400 on the TEM sample support metal mesh 'grids'.

The field experiments have been performed with Pecherianka variety spring wheat plants. The plants of Triticum aestivum L. have been grown in field conditions on research areas (area $50 \mathrm{~m}^{2}$ ) of Zabolotny Institute of Microbiology and Virology of NASU. The following scheme has been used for experiments: 1 - control (water); 2 - pre-sowing treatment of seed with $1 \%$ solution of $\mathrm{Ag}+\mathrm{Cu}$; 3 - pre-sowing treatment with 1\% solution micro fertilizer Avatar-1 (organic); 4 - pre-sowing treatment of seed with $1 \%$ solution BP I-Se.

Artificial inoculation of Pecherianka variety spring wheat plants in the boot stage was carried out by bacterial suspension of the strain of $P$. syringae pv. atrofaciens D13 (causal agent of basal glume rot of cereals). Density of the suspension was $1 \times 10^{9} \mathrm{CFU} / \mathrm{ml}$. Artificial inoculation was done by injecting a bacterial suspension into a stem in 10-fold repeatability on each of the variants. 14 days after bacterial infection, typical visual manifestations of disease symptoms have been evaluated in conditional units (number of spots, strokes, total area of damage) in comparison with control (without treatment) and experimental plants (pre-sowing treatment condition). 4-point of the scale have been used for estimated of the disease symptoms. 


\section{RESULTS AND DISCUSSION}

Researches were showed a decrease in the degree of visual display of bacterial disease at artificial inoculation with the causative agent of basal glume rot of cereals - P. syringae pv. atrofaciens D13 in condition pre-sowing treatment of wheat seed with solutions of nanosized metal citrates (1\% Ag-Cu) and $0.1 \%$ of Avatar-1 (Co $+\mathrm{Cu}+\mathrm{Zn}+\mathrm{Fe}+\mathrm{Mn}+\mathrm{Mo}+\mathrm{Mg})$ and $1 \%$ solution of biologically active iodine in the composition of I-Se composition.

In variants with pre-sowing treatment of wheat seeds by nanoparticles I-Se, the manifestation of artificial infection decreased and amounted to 0.9 number, compared to control (without treatment) - 2.2 number (Fig. 1).

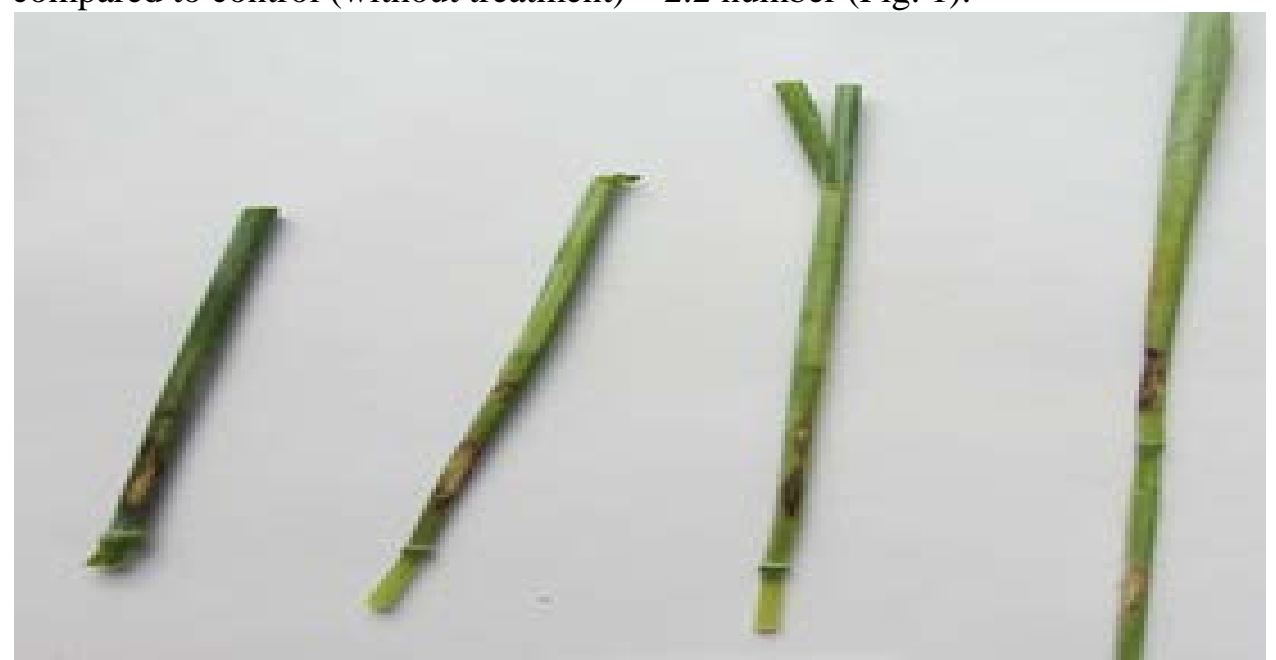

Fig. 1. Symptoms of a disease at artificial inoculation Pseudomonas syringae pv. atrofaciens D13 (control).

To check the biocides effectiveness, bacterial strains isolation from artificial inoculated of plants have been performed. After bacteriological analysis of the pieces of the infected tissue, colonies were selected and accounted, which according to morphological properties are similar to Pseudomonas syringae. Then the oxidase activity test was performed, as well the oxidase-positive reaction of micro agglutination on glass with antiserum to the strains $P$. syringae pv. atrofaciens.

It has been demonstrated, that $12 \%$ of the isolated bacteria of $P$. syringae pv. atrofaciens and 2.2 conditional units on a scale typical visual manifestations of bacterial disease of wheat was corresponded (Table 1). In other variants of the experiment, up to $10 \%$ of these bacteria were detected. In the variant with presowing treatment of wheat seeds BP I-Se, where artificial infection was 0.9 number, found $4 \%$ of cells $P$. syringae pv. atrofaciens.

Consequently, in wheat plants, the effects of various treatment by investigated of biologically active substances showed a significant decrease in the percentage of cells $P$. syringae pv. atrofaciens. The next step in our analysis was to detect the effect of the substances investigated with biocidal properties on the morphology of $P$. syringae cells in the short-term effect of nanocitrates, 
performed by electron microscopy. An electron microscopic image of the test substances at 1\% concentration is visualization in Fig. 2 (A-I).

Table 1. Influence of pre-sowing treatment of wheat with biologically active substances on the percentage of the causative agent of basal glume rot of cereals in plant tissues

\begin{tabular}{|c|c|}
\hline The variants of treatment & $\begin{array}{c}\text { The content of P. syringae pv. } \\
\text { atrofaciens D13 after reisolation (\%) }\end{array}$ \\
\hline Control (without treatment) & 12 \\
\hline pre-sowing treatment of 1\% Ag-Cu solution & 10 \\
\hline $\begin{array}{c}\text { pre-sowing treatment of 0,1\% Avatar-1 } \\
\text { solution (Co+Cu+Zn+Fe+Mn+Mo+Mg) }\end{array}$ & 10 \\
\hline pre-sowing treatment of 1\% BP I-Se solution & 4 \\
\hline
\end{tabular}
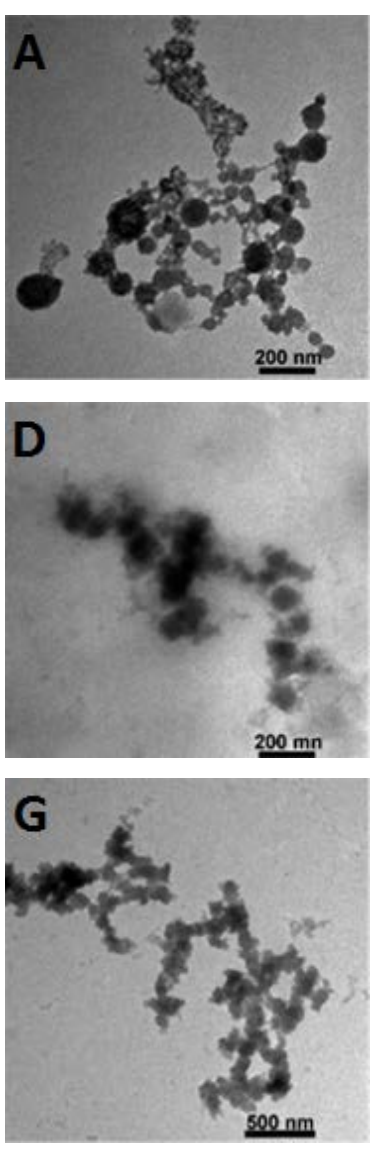
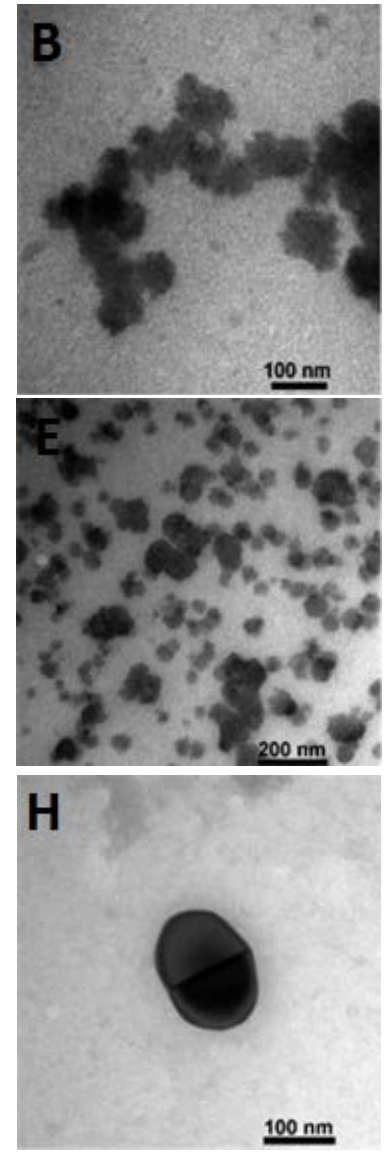
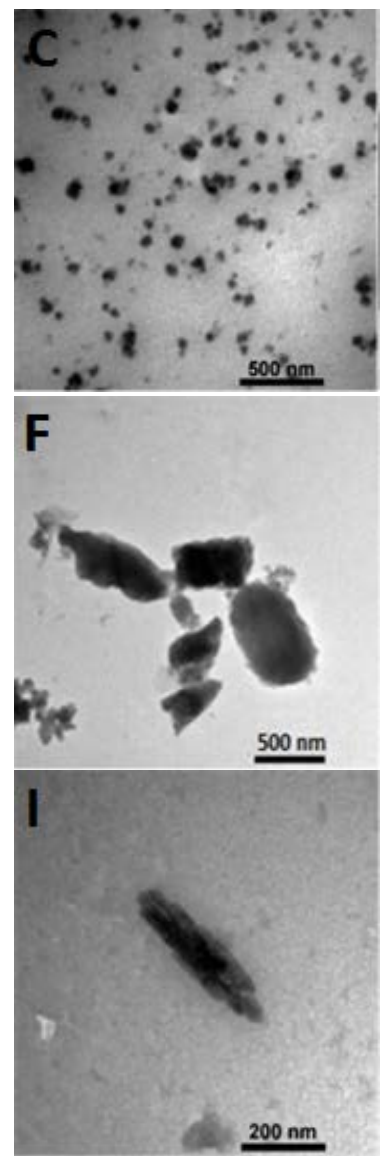

Fig. 2. Microphotographs of Trans missive electron microscopy of the substances investigated of biological activity substances with biocidal properties: Ag-Cu (AC); Avatrar-1 (D-F); I-Se (G-I). 
Compared to the native, intact cells of bacteria $P$. syringae (Fig. 3, A-E), morphological changes of the cell membranes and bacterial cells are observed for the action of test substances, the of which is clearly seen in the microphotographs obtained by Trans mission electron microscopy (Figs 4-6). It has been found destruction of the cell membrane, which have lead to loss of homeostasis, bacteriolysis and cell death as a result by exposed to bacterial cells of the components experimental 1\% solutions (Avatar-1, Ag-Cu and BP I-Se). (Fig 4, A-H; Fig. 5, B-G; Fig.6, A-G).
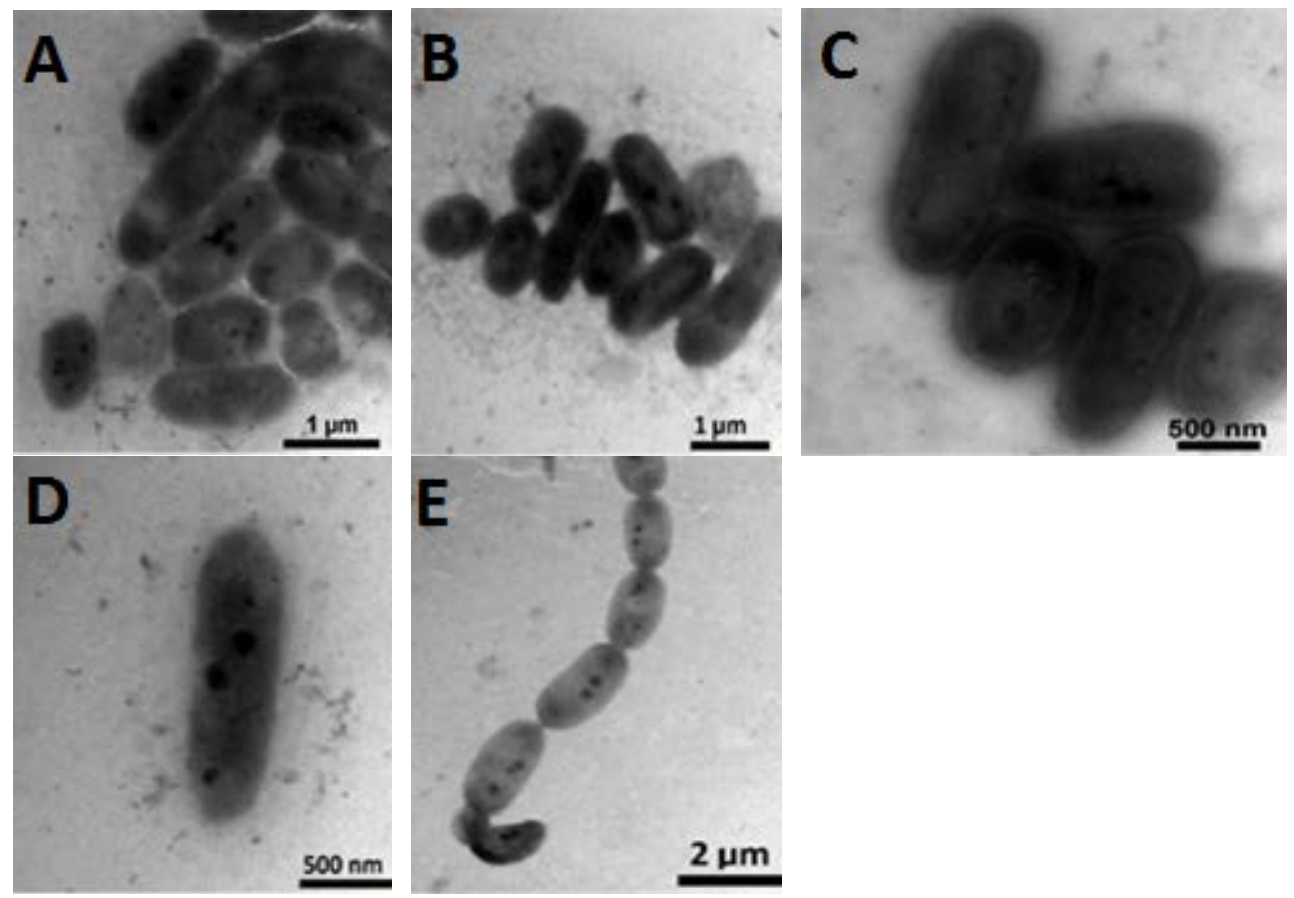

Fig. 3. Microphotographs of Trans missive electron microscopy of Pseudomonas syringae pv. atrofaciens D13 cells (A-E).

Reduction of basal glume rot of cereals the visual symptoms and the percentage of isolated Pseudomonas syringae pv. atrofaciens D13 cell was detected by pre-sowing treatment of wheat seeds by experimental biocides, have been attributable to explained by structural changes in the bacterial cells of the pathogen, which lead to a reduction of viable forms of bacteria due to damage of both, the cell wall and internal contents. Thus, the studied carboxylates of nanoparticles and the bio preparation of iodine-selenium have an actual bactericidal activity in a small concentration. Consequently, the effect of the studied biocides was caused the destruction of the cell wall, its cracking, which lead to the leakage of cytoplasmic content and subsequent cell lysis. 

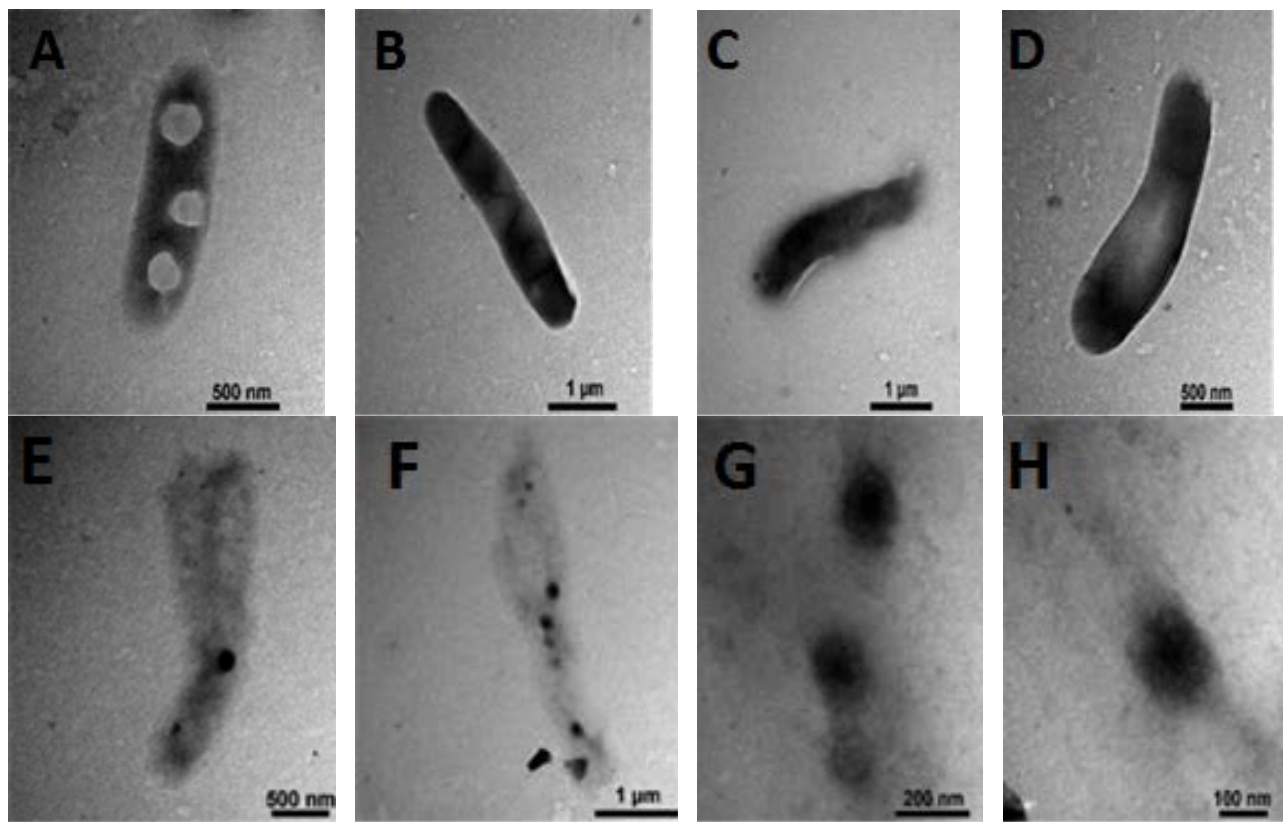

Fig.4. Microphotographs of Trans missive electron microscopy of Pseudomonas syringae pv. atrofaciens cells at action $1 \%$ solution of citrate nanocomposite of Ag-Cu (A-H).
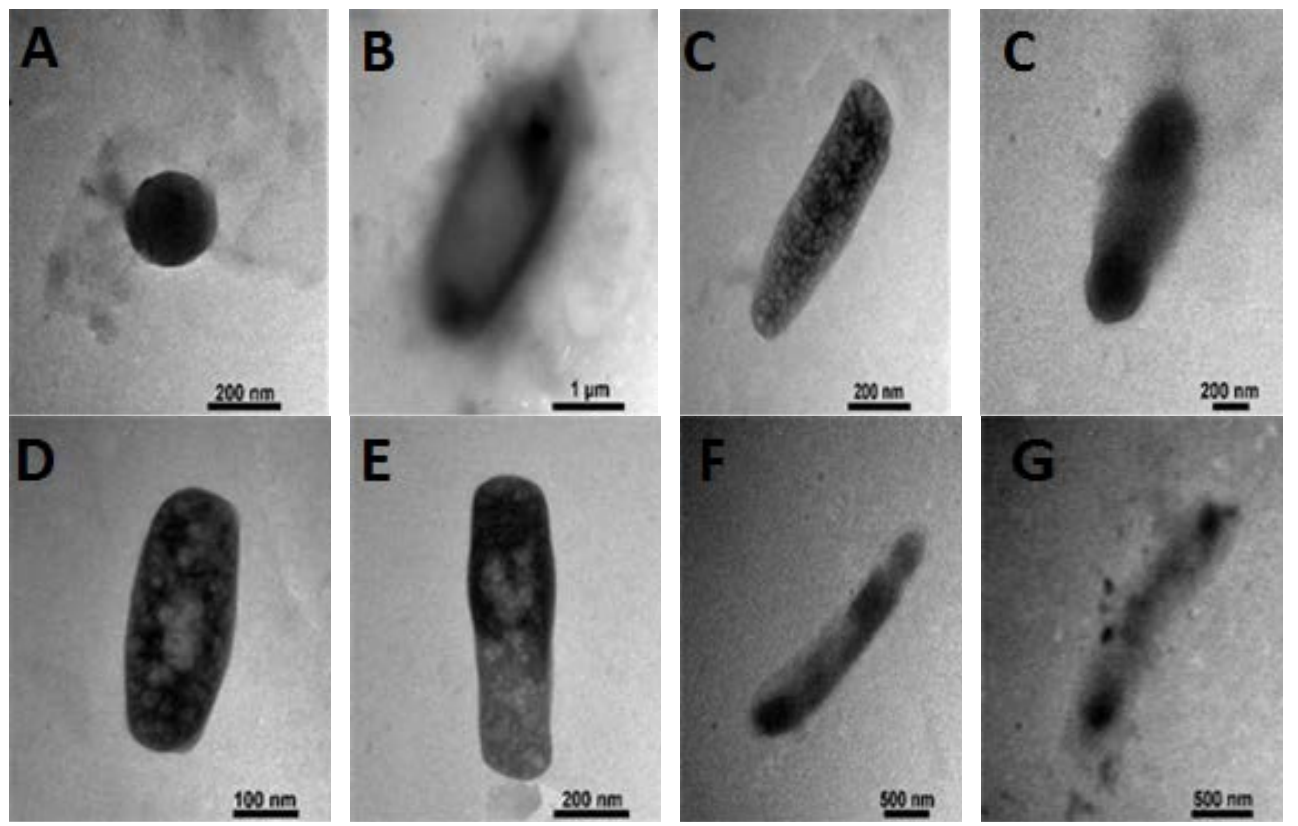

Fig.5. Microphotographs of Trans missive electron microscopy of Pseudomonas syringae pv. atrofaciens cells at actions $1 \%$ Avatar-1 solution (citrate of nanocomposite Co;Cu;Zn;Fe;Mn;Mo;Mg) (A-G). 

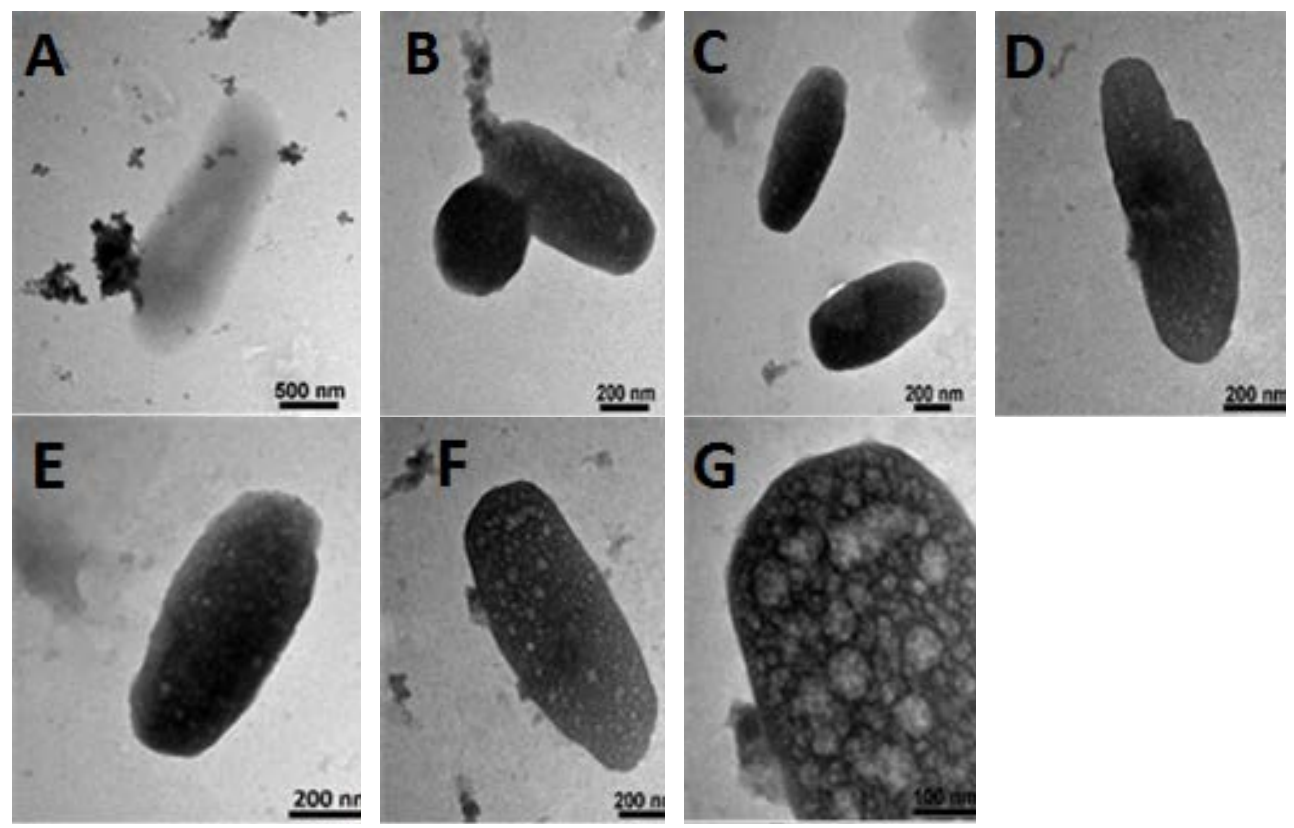

Fig.6. Microphotographs of Trans missive electron microscopy of Pseudomonas syringae pv. atrofaciens cells at action of BP I-Se (A-G).

Similar effects of experimental elements in the form of nanoparticles are given in Siddiqi K.S. et al. (2018), which shows that Ag NPs stops the development and multiplication of many bacteria by binding $\mathrm{Ag} / \mathrm{Ag}^{+}$to the biomolecules present in microbial cells. Due to its small size, Ag nanoparticles are diffused into the cell, destroying the cell wall. In the work of Ahmada A. et al. (2017) shows that chitosan-modified silver nanoparticles lead to the destruction of the bacterial membrane potential, inducing a high level of intracellular active forms of oxygen (AFO). In studies of antibacterial activity of nanoparticles of copper, cobalt, and nickel in the form of chelated nanoparticles, which is an intermediate form between nanoparticles and ions, it is assumed that their action is due to the binding of amino acids (DeAlba-Montero I. et al., 2017). Thus, the investigated forms of biocides are suitable as agents with bactericidal action for possible application in crop production, but further research is needed to find out the optimal parameters for their use for this purpose.

\section{CONCLUSIONS}

It was found out that during pre-seed treatment of seeds with $1 \%$ solutions of citrates of Ag-Cu nanoparticles, as well as the nanocomposite - $\mathrm{Co}$; $\mathrm{Cu}$; $\mathrm{Zn}$; Fe; Mn; Mo; Mg (Avatar-1) and biopreparation of iodine-selenium there was a significant inhibition of the development of Pseudomonas syringae pv. atrofaciens cells with reducing their viability. With method Trans missive electron microscopy was shown, that solutions of citrates of Ag-Cu nanoparticles, 
as well as the nanocomposite - Co; Cu; Zn; Fe; Mn; Mo; Mg (Avatar-1) and biopreparation of iodine-selenium have an actual bactericidal activity in a small concentration, that reduction of viable forms of bacteria due to damage to the cell wall.

\section{REFERENCES}

Ahmada A., Weia Y., Syed F. et al. (2017): The effects of bacteria-nanoparticles interface on the antibacterial activity of green synthesized silver nanoparticles. Microbial Pathogenesis, Vol. 102: 133-142.

DeAlba-Montero I., Guajardo-Pacheco J., Morales-Sánchez E. et al. (2017): Antimicrobial Properties of Copper Nanoparticles and Amino Acid Chelated Copper Nanoparticles Produced by Using a Soya Extract. Bioinorg Chem Appl. Vol. 2017: 1064918.

Gvozdyak R.I., Pasichnyk L.A., Yakovleva L.M. et al. (2011): Phytopatogenni bakterii, T.1, Kyiv: Interservis.

Kalinichenko A., Pasichnyk L., Osypenko S. et al. (2017): Bacterial diseases of bioenergy plants. Ecological Chemistry and Engineering A., Nr 2 (24):169-191.

McDonnell G., Russell A.D. (1999): Antiseptics and Disinfectants: Activity, Action, and Resistance. Clin Microbiol Rev. 12(1): 147-179.

Patyka V., Buletsa N., Pasichnyk L. et al. (2016): Specifics of pesticides effects on the phytopathogenic bacteria. Ecological Chemistry and Engineering S, Vol. 23(2): 311-331.

Patyka V.P., Pasichnyk L.A., Gvozdyak R.I. et al. (2017): Phytopatogenni bakterii, T.2, Vinnica: TOV Vindruk.

Siddiqi K. S., Husen A., Rao R.A.K. (2018): A review on biosynthesis of silver nanoparticles and their biocidal properties. Journal of Nanobiotechnology, $\mathrm{Nr}$ 16(1): 14.

Šramkováa Z., Gregováb E., Šturdík E. (2009): Chemical composition and nutritional quality of wheat grain. Acta Chimica Slovaca, Vol. 2(1): 115-138. 